\title{
Percent Change From Nadir in Sum of
}

\section{Area}

National Cancer Institute

\section{Source}

National Cancer Institute. Percent Change From Nadir in Sum of Area. NCI Thesaurus.

Code C126057.

The most recently recorded sum of areas minus the lowest sum of diameters previously recorded divided by the lowest sum of areas previously recorded, multiplied by 100 . 